\title{
Osmotic demyelination syndrome
}

\author{
Christian Börnke, ${ }^{1}$ Gisa Ellrichmann, ${ }^{1}$ Ruth Schneider, ${ }^{1}$ Carsten Lukas ${ }^{2}$
}

${ }^{1}$ Department of Neurology, St. Josef Hospital, Bochum Germany

${ }^{2}$ Department of Radiology, St. Josef Hospital, Bochum Germany

\section{Correspondence to} Dr Christian Börnke, christian.boernke@web.de

Accepted 13 June 2014

\section{(a) CrossMark}

To cite: Börnke $C$ Ellrichmann $\mathrm{G}$, Schneider $\mathrm{R}$ et al. BMJ Case Rep Published online: [please include Day Month Year] doi:10.1136/bcr-2014204742

\section{DESCRIPTION}

A 25-year-old man presented with progressive impairment of consciousness, ocular bobbing and tetraparesis. Since the age of 3 he had received substitution therapy for central diabetes insipidus after surgical treatment of a craniopharyngioma. Accidental disruption of his intranasal desmopressin treatment 1 day before admission led to an increase of serum sodium of $29 \mathrm{mmol} / \mathrm{L}$ in less than $24 \mathrm{~h}$. Initial MRI and cerebrospinal fluid examination were unobtrusive. Despite extensive symptomatic treatment the patient developed signs and symptoms of severe encephalopathy. Follow-up MRI 5 days later revealed widespread grey matter oedema with diffuse high signal and swelling of the cortex (figure $1 \mathrm{~A}$, asterisk) and caudate nuclei (figure $1 \mathrm{~A}$, arrowhead) on fluid attenuation inversion recovery sequences. Moreover, diffusion weighted imaging showed restricted diffusion in the entire cortex and

\section{Learning points}

- It is important to identify patients at risk from osmotic demyelination syndrome and to correct their hyponatraemia appropriately.

- Although it is recognised that osmotic demyelination syndrome is a rare disease, its dramatic clinical course points out the importance in different disciplines.

- Since osmotic demyelination syndrome is an iatrogenic disease its early recognition and effective prevention is mandatory. internal capsule (figure 1B, C) consistent with extrapontine myelinolysis, an osmotic demyelination syndrome that may follow rapid correction of sodium in hyponatraemic patients. Usually, regions of high grey and white matter apposition show focal and bilateral affection. ${ }^{1}{ }^{2}$ Prevention is essential owing to the lack of established treatment options. ${ }^{2}$ Since neither clinical nor radiological features are predictive, other factors determine individual prognosis: low Glasgow Coma Scale at hospital entry and during the course of disease, severe hyponatraemia and additional hypokalaemia indicate a poor outcome. $^{3}$

Contributors $C B$ drafted the manuscript, surveyed treatment of the described case and provided general support. GE and RS drafted the manuscript, searched for literature and analysed clinical and laboratory results. $\mathrm{CL}$ analysed MRI and prepared it for manuscript. He also supported drafting the manuscript.

\section{Competing interests None.}

Patient consent Obtained.

Provenance and peer review Not commissioned; externally pee reviewed.

\section{REFERENCES}

1 Gocht A, Colmant HJ. Central pontine and extrapontine myelinolysis: a report of 58 cases. Clin Neuropathol 1987:6:262-70.

2 Martin RJ. Central pontine and extrapontine myelinolysis: the osmotic demyelination syndromes. I Neurol Neurosurg Psychiatry 2004;75(Suppl III):iii22-8.

3 Kallakatta RN, Radhakrishnan A, Fayaz RK, et al. Clinical and functional outcome and factors predicting prognosis in osmotic demyelination syndrome (central pontine and/or extrapontine myelinolysis) in 25 patients. J Neurol Neurosurg Psychiatry $2011: 82: 326-31$ 


\section{Images in...}

Copyright 2014 BMJ Publishing Group. All rights reserved. For permission to reuse any of this content visit http://group.bmj.com/group/rights-licensing/permissions.

BMJ Case Report Fellows may re-use this article for personal use and teaching without any further permission.

Become a Fellow of BMJ Case Reports today and you can:

- Submit as many cases as you like

- Enjoy fast sympathetic peer review and rapid publication of accepted articles

- Access all the published articles

- Re-use any of the published material for personal use and teaching without further permission

For information on Institutional Fellowships contact consortiasales@bmjgroup.com

Visit casereports.bmj.com for more articles like this and to become a Fellow 